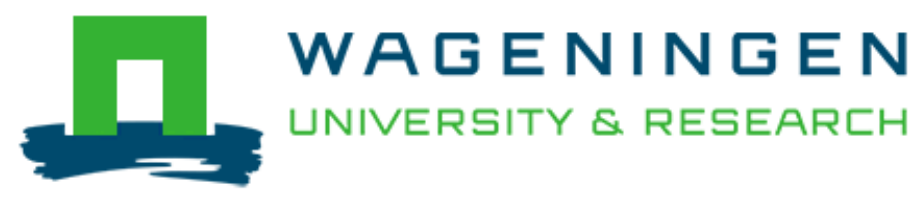

\author{
Ammonia emissions from grazing \\ Vertregt, N., \& Rutgers, B.
}

This is a "Post-Print" accepted manuscript.

This version is distributed under a non-commercial no derivatives Creative Commons (c) (1) (3) $\Theta$

reproduction in any medium, provided the original work is properly cited and not used for commercial purposes. Further, the restriction applies that if you remix, transform, or build upon the material, you may not distribute the modified material.

Please cite this publication as follows:

Vertregt, N., \& Rutgers, B. (1991). Ammonia emissions from grazing. In V. C. Nielsen, J. H. Voorburg, \& P. L'Hermite (editors), Odour and ammonia emissions from livestock farming: Proceedings of a seminar, Silsoe, UK, 26-28 March 1990 (blz. 177-183). Routledge. https://doi.org/10.4324/9780203215975-24

You can download the published version at:

https://doi.org/10.4324/9780203215975-24 


\title{
AMMONIA EMISSIONS FROM GRAZING
}

\section{N. VERTREGT and $B$. RUTGERS}

\author{
Centre for Agrobiological Research \\ Bornsesteeg 65, 6700 AA Wageningen, The Netherlands
}

Summary

The ammonia-N emissions from axtificially prepared urine patches on grassland on a sandy soil were measured with a windtunnel method. Artificial urine with a N-content of $6-12 \mathrm{~g} .1^{-1}$ was applied at a rate of $51 \mathrm{~m}^{-2}$. At a urine application rate of $600 \mathrm{~kg} \mathrm{~N} . \mathrm{ha}^{-1}$ the ammonia-N emission varied between $6 \%$ and $19 \%$ (mean $13 \%$ ) of the urine-N.

It was argued that the emission rate is proportional to the urine-N concentration. The ammonia emission rate is $10 \%$ at an average urine-N concentration of $9 \mathrm{~g} \cdot \mathrm{I}^{-1}$. The results of the emission measurements were confirmed by $\mathbb{N}$-budget analyses of the urine patch system.

The total ammonia emissions from grazed pastures at various levels of $\mathrm{N}$-supply were calculated using known data on grass production, intake and digestion. The calculated ammonia-N emissions varied from $16 \mathrm{~kg} \mathrm{~N} \cdot \mathrm{ha}^{-1}$ at a $\mathrm{N}$ supply of $100 \mathrm{~kg} \cdot \mathrm{ha}^{-1}$ to $38 \mathrm{~kg}^{-\mathrm{ha}^{-1}}$ at a $\mathrm{N}$-supply of $500 \mathrm{~kg} \cdot \mathrm{ha}^{-1}$. The calculated ammonia emissions were similar to the results of measurements in grazed fields with the micrometeorological mass balance method. At low levels of $\mathrm{N}-\mathrm{supply}$ the mass balance data were disproportionallr low, probably as a result of lower urine- $N$ concentration during grazing and an underestimation of the emission by the mass balance method due to a relatively high background interference.

\section{INTRODUCTION}

Several years ago it was recognized that the ammonia emissions from animal excretion contribute significantly to the eutrophication and acidification of the natural environment.

About $60 \%$ of the ammonia emission in the Netherlands is attributed to cattle and $60 \%$ of the $\mathrm{N}$-excretion of cattle occurs during the grazing period. For this reason the ammonia emission during grazing was studied in some detail. Two approaches were used in The Netherlands. In the CABO experiments use was made of a windtunnel placed over artificial urine patches on $1 \mathrm{~m}^{2}$ plots of grassland (1). The NMI measured ammonia volatilization from grazed pastures with a micrometeorological mass balance method (2). When properly applied both methods give equal results (3).

The ventilation rate in the tunnel has to be sufficiently high to ascertain climatic conditions in the tunnel similar to ambient conditions. The accuracy of the two methods will be discussed and the total ammonia emission from grazed pastures will be calculated.

The work was part of the Dutch Priority Program on Acidification.

\section{EXPERIMENTS}

Windtunnel experiments were carried out in 1986 and 1987 on grassland on a sandy soil at the experimental farm Droevendaal at Wageningen. Air was filtered ammonia-free by forcing it through an airconditioning filter impregnated with orthophosphoric acid. The ammonia-free air was ventilated over the plots prepared with artificial urine according the Doak (4). The 
urine application rate was $600 \mathrm{~kg} \mathrm{~N} \cdot \mathrm{ha}^{-1}, 5$ liter per $\mathrm{m}^{2}$ of urine with a concentration of $12 \mathrm{~g} \mathrm{~N}^{-1}$. The ventilation rate was $1200 \mathrm{~m}^{3}$ per hour, or 1.5 meter per second through a tunnel of 2 meter length, 0.55 meter width and 0.60 meter height. The air was continuously sampled after passage through the tunnel. The ammonia emission was calculated by multiplying the quantity of ammonia absorbed from the sampled air with the ratio of the measured volume of the ventilation air and the measured volume of the sampled air.

\section{RESULTS AND DISCUSSION}

Typical course lines for the ammonia emission and the $\mathrm{pH}$ of the soil surface are presented in Figure 1. The $\mathrm{pH}$ of the soil increases from 6 to 9 within a day after urine application. The $\mathrm{pH}$ decreases slowly to the initial value in a period of about 20 days. The ammonia volatilization rate declines rapidly during the first days after urine application.

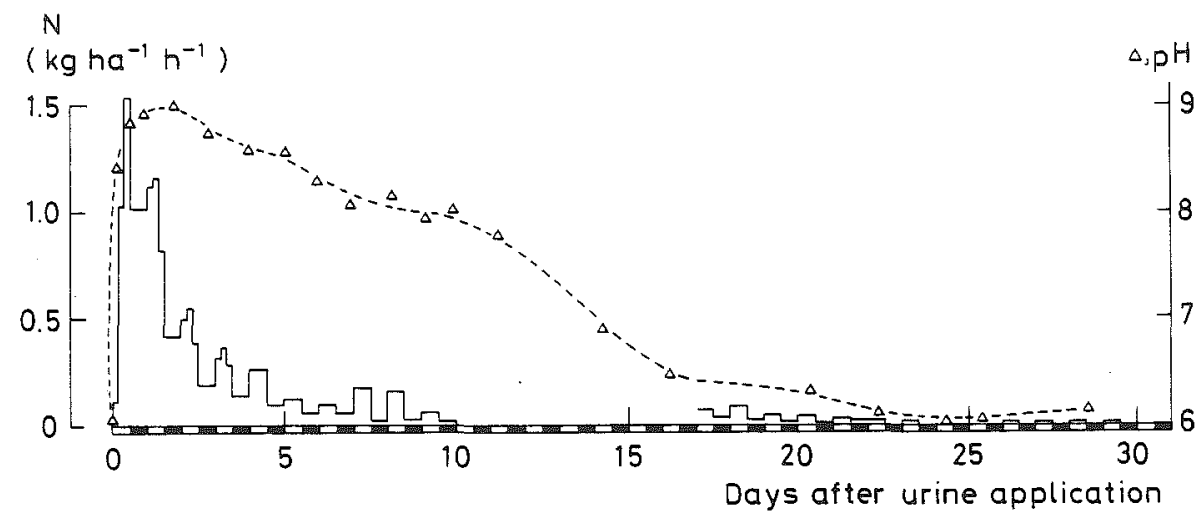

Fig. 1. Ammonia volatilization, $\mathrm{kg} \mathrm{N} \cdot \mathrm{ha}^{-1} \mathrm{~h}^{-1}$ and soil surface $\mathrm{pH}$ following a urine-N application of $600 \mathrm{~kg} \cdot \mathrm{ha}^{-1}$.

The total ammonia-N emissions over periods of 10 days are represented in figure 2 for 17 experiments on sandy soil with a urine-N application rate of approximately $600 \mathrm{~kg}$ per ha. The total $\mathrm{N}$ emission varied between 23 and $98 \mathrm{~kg} \mathrm{~N} \cdot \mathrm{ha}^{-1}$. No definite relations between temperature, global radiation, soil moisture content or $\mathrm{pH}$ of the soil surface and the ammonia emission could be established.

Obviously the ammonia volatilization depends on more factors than the factors mentioned. Part of the emission is governed by physical and chemical reactions in the upper soil layer. Part of the urine adheres to the leaf and litter layer and will volatilize following different kinetics. As the total emission is relatively small, a substantial fraction will volatilize from the leaf and litter layer.

The volatilization from the top soil layer depends on the ammonium concentration in this layer. It is to be expected that the ammonium transport in the upper soil layers is influenced by the soil moisture content and the water supply to the soil. However, as stated before, no clear relation between soil moisture content and volatilization level was found. 
The average emission during the first 10 days after urine application amounts to $10 \%$ of the urine- $\mathbb{N}$ applied. The daily emission decreased to zero a month after that application. Consequently the total ammonia emission in a period of a month is $13 \%$ of the urine-N.

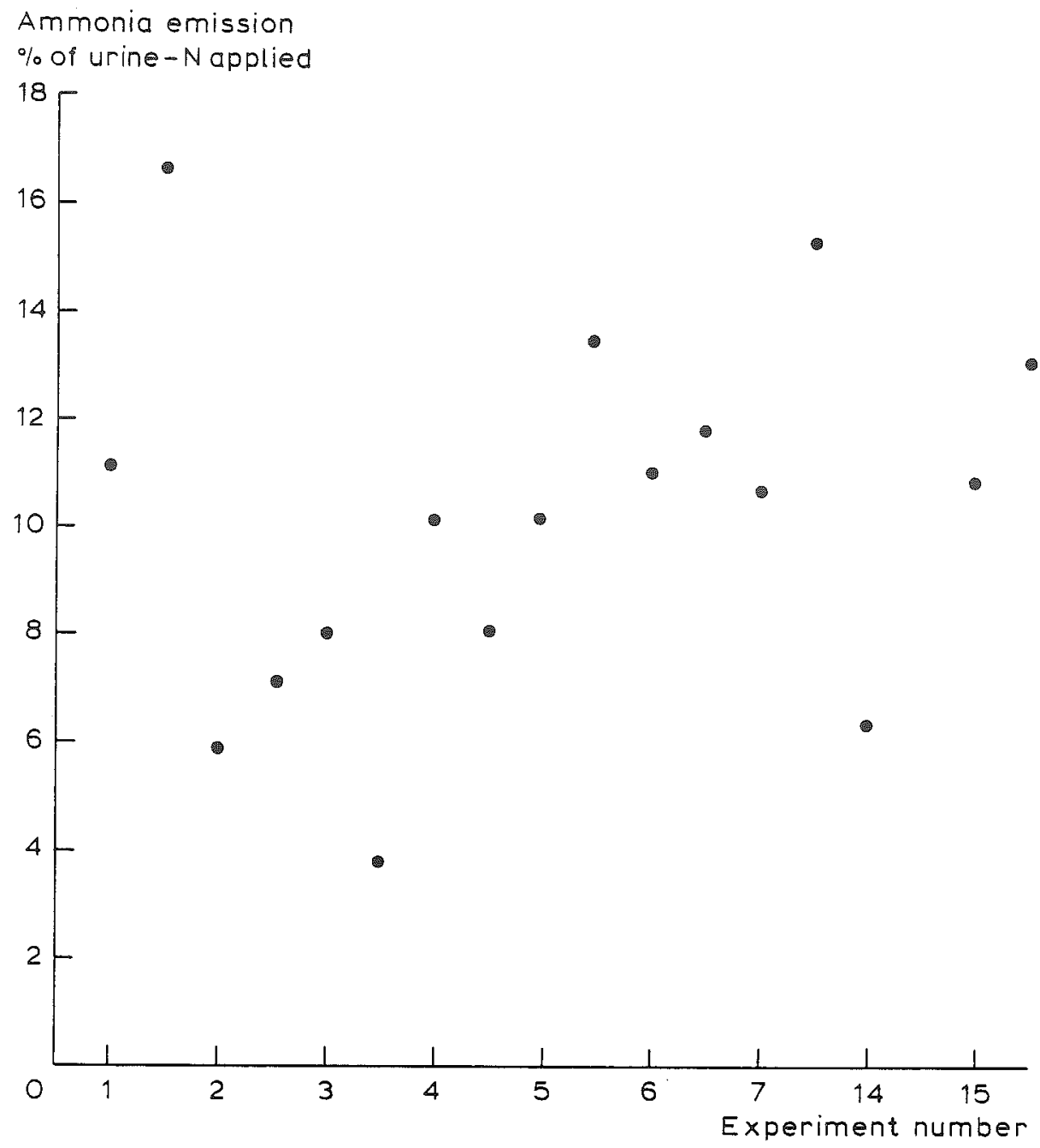

Fig. 2. Ammonia- $N$ emission in $\%$ of $N$ applied for successive identical experiments on sandy soil.

This value for the ammonia emission however, seems to be an overestimation of the true value of the emission under field conditions according to the following reasons. During the experiment it was recognized that the average $\mathrm{N}$-concentration in the urine fluctuates around $9 \mathrm{~g}$ per liter. In the experiments artifical urine with a $\mathrm{N}$-concentration of $12 \mathrm{~g}$ per liter was used. It is assumed that at least the relatively high ammonia emission during the first days after urine application is proportional to the urine- $\mathbb{N}$ concentration as this emission originates mainly from the urine adhering to the leaf and litter layer (6). Therefore the average ammonia emission of urine with a $\mathrm{N}$-concentration of $9 \mathrm{~g}$ per liter can be estimated at $11 \%$ of the urine-N application.

As mentioned before, the effect of soil temperature and soil moisture content on the ammonia emission could not be established from the 
experiments. However, on the average the temperature under the tunnel was about $1{ }^{\circ} \mathrm{C}$ higher than outside it. The soil moisture content decreased gradually during the experimental period. As a consequence the measured ammonia emission in the tunnel system is at least theoretically somewhat higher than under field conditions. This effect is only temporary, as the volatilization is restricted by the ammonium transport to the topsoil layer. The correction for the slightly deviating temperature and soil moisture content on the ammonia volatilization rate has been estimated at $10 \%(5)$.

The totalized corrections reduce the estimated average ammonia emission to $10 \%$ of the urine-N at an urine-N concentration of $9 \mathrm{~g} .1^{-1}$.

The ammonia emission from grazed pastures was measured directly with the micrometeorological mass balance method on plots that were fertilized

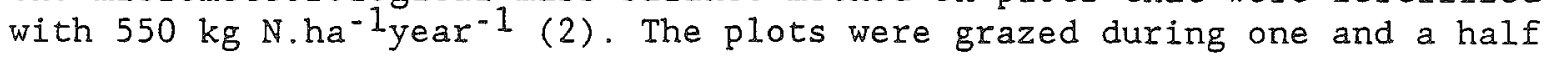
day with a stocking density of 60 to 120 cows per hectare. The mean ammonia emission was determined to be $8 \%$ of the estimated excreted $N$. The true ammonia emission may be underestimated by the mass balance method. The first reason for this statement is that the limits of the measuring system are not exactly defined. Some of the volatilized ammonia may escape beyond the assumed limits of the ammonia profile.

Secondly the background concentration measured at the windward side of the field or at a high position on the central mast may be overestimated i.e. because of back diffusion. Consequently the calculated net emission has a relatively low value.

Thirdly with the mass balance method the net emission is measured. This net emission is the difference between the ammonia emission and the ammonia deposition from the atmosphere. As the windtunnels are ventilated with ammoniafree air this third factor is absent in the windtunnel method. In the Netherlands the atmospheric deposition can be estimated on $0,5 \mathrm{~kg}$ per hectare in a 10 -day period. It can roughly be estimated that with the factors mentioned the ammonia emission as measured by the mass balance method has to be corrected from $8 \%$ to $10 \%$ of the excreted $\mathrm{N}$. It must be borne in mind that the variation in ammonia emission is considerable. However, both methods agree on the fact that $90 \%(85.95 \%)$ of the urine-N does not volatilize from urine patches.

To validate the data on ammonia emission we studied the conversion of the urine- $\mathrm{N}$ in urine patches in more detail.

\section{N-BUDGET OF URINE PATCHES}

Before the start of the experiments and ten days after urine application, soil samples were taken to a sufficient depth and analysed for the ammonium and nitrate content (6). At the same time the grass was sampled and analyzed. In many experiments the $\mathrm{N}$-uptake by the grass was negligible, on the average $10 \mathrm{~kg} \mathrm{~N} \cdot \mathrm{ha}^{-1}$ in a 10 -day period, partly because of growth inhibition due to the urine application. For all experiments on sandy soils in which $600 \mathrm{~kg} \mathrm{~N} . \mathrm{ha}^{-1}$ was applied the relevant $\mathrm{N}$-fractions at the $10^{\text {th }}$ day after urine application are plotted in Figure 3. For each experiment the remaining part of the urine-ammonium (urea) $-\mathrm{N}$ is plotted on the abscissus against the amounts of volatilized ammonia-N, nitrate-N and $\mathrm{N}$ not accounted for $\left(\mathrm{N}_{\text {naf }}\right.$ ) on the ordinate. The calculated regression lines for $\mathrm{NH}_{3}, \mathrm{NH}_{3}+\mathrm{NO}_{3}$ and $\mathrm{NH}_{3}+\mathrm{NO}_{3}{ }^{-}+\mathrm{N}_{\text {naf }}$ against the soil ammonium- $\mathrm{N}$ are drawn in figure 3 . In a number of experiments the budget loss, $\mathrm{N}_{\text {naf }}$, was relatively high. Theoretically, the budget loss could be attributed to inaccurate sampling methods. In some experiments a nitrification inhibitor was applied in order to prevent a rapid decrease in $\mathrm{pH}$. In these experiments the final ammonium content of the soil was high, the 
nitrification and the $\mathbb{N}$-budget loss were both very low. So it was concluded that the sampling procedure was correct.

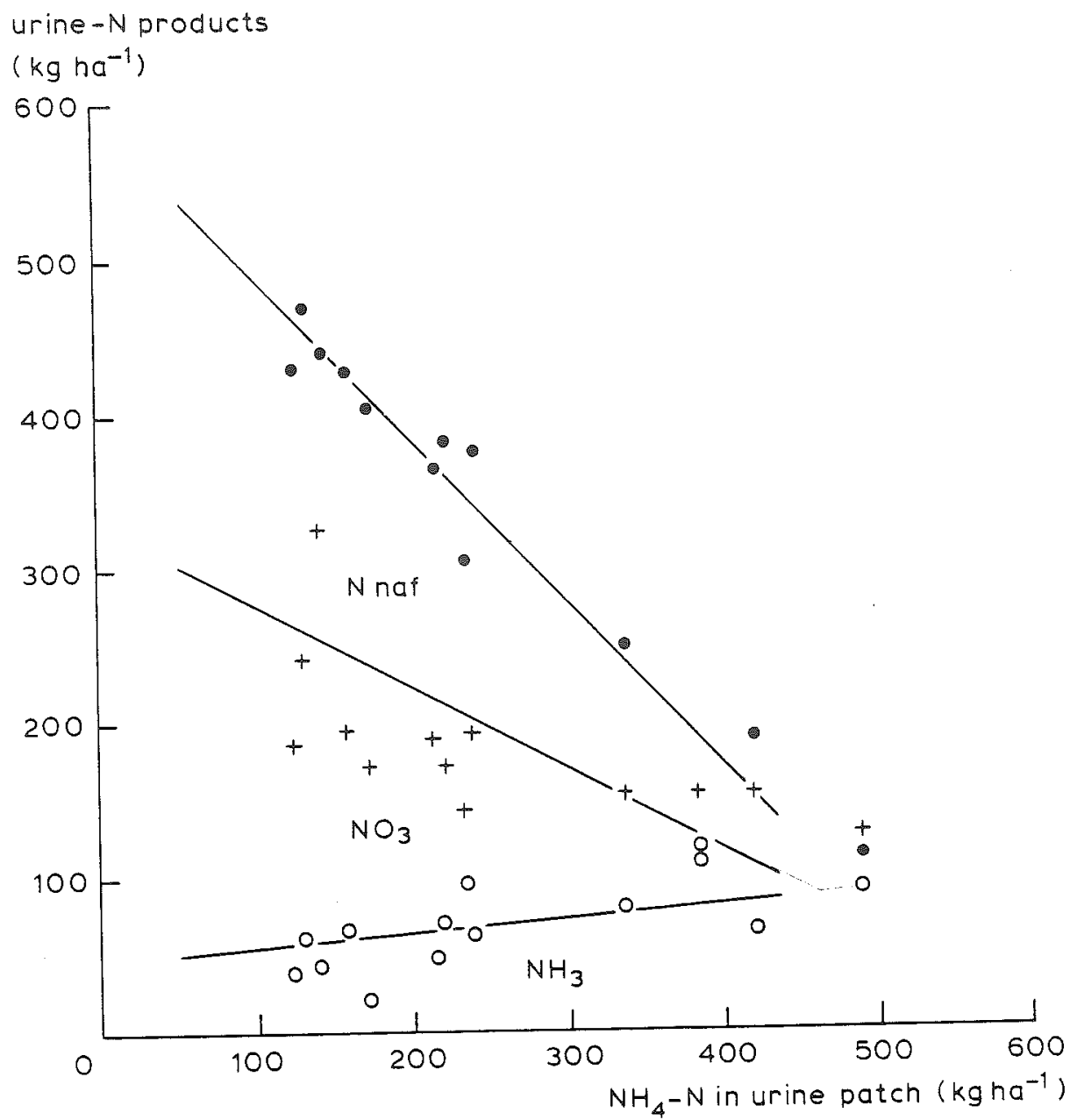

Fig. 3. N-budget of a urine patch, 10 days after application of $600 \mathrm{~kg}$ urine- $\mathrm{N} \mathrm{ha}{ }^{-1}$. $\mathrm{x}$-axis: $\mathrm{NH}_{4}^{+}-\mathrm{N}$ in soil. $\mathrm{y}$-axis: $\mathrm{NH}_{3}-\mathrm{N}$ volatilized (o), $\mathrm{NH}_{3}-\mathrm{N}+\mathrm{NO}_{3}^{-}-\mathrm{N}$ in soil (+), $\mathrm{NH}_{3}-\mathrm{N}+\mathrm{NO}_{3}-\mathrm{N}+\mathrm{N}$ not accounted for $(\bullet)$.

In experiments with a low final ammonia content in the soil, the nitrate content is high, the ammonia volatilization is relatively low and the amount of $\mathrm{N}$ not accounted for is high. The ammonia volatilization is high under conditions of low nitrification and high $\mathrm{pH}$, but the increase in ammonia emission is not proportional to the soil ammonium content. Summarizing the ammonia volatilization is not only restricted by the nitrification but also by interactions between ammonium and the soil complex. The $\mathrm{N}$-budget loss is coupled with the nitrification. Obviously a large fraction of the urine- $N$ gets lost during nitrification by a chemodenitrification process.

5. CALCULATION OF THE AMMONIA EMISSION FROM GRAZED PASTURES AT DIFFERENT RATES OF FERTILIZATION

The yield and nitrogen content of grass in relation to the $\mathrm{N}$ fertilization is calculated from a large number of measurements on sandy soils in the Netherlands (7). 
The grass intake of dairy cows is assumed to be $14.5 \mathrm{~kg}$ dry matter per day. The calculated dry matter and $N$ intakes are plotted in quadrant $I$ of Figure 4. The milk production is $20 \mathrm{~kg}$ per day with a nitrogen content of $0.53 \%(8)$. The urine and faeces excretions are calculated using the digestion coefficients published in (9) and the milk production. The calculated values for the urine and faeces excretions are plotted in quadrant II. The ammonia volatilization emission is fixed at $10 \%$ of the $\mathrm{N}$-excretion. The calculated emissions are plotted in quadrant III and IV. By reducing the fertilization from 400 to $200 \mathrm{~kg} \mathrm{~N}$ per ha. year the ammonia emission decreases from 33 to $21 \mathrm{~kg}$ per hectare per year. The stocking density decreases at the same time from 3.9 to 3.1 dairy cows per hectare.

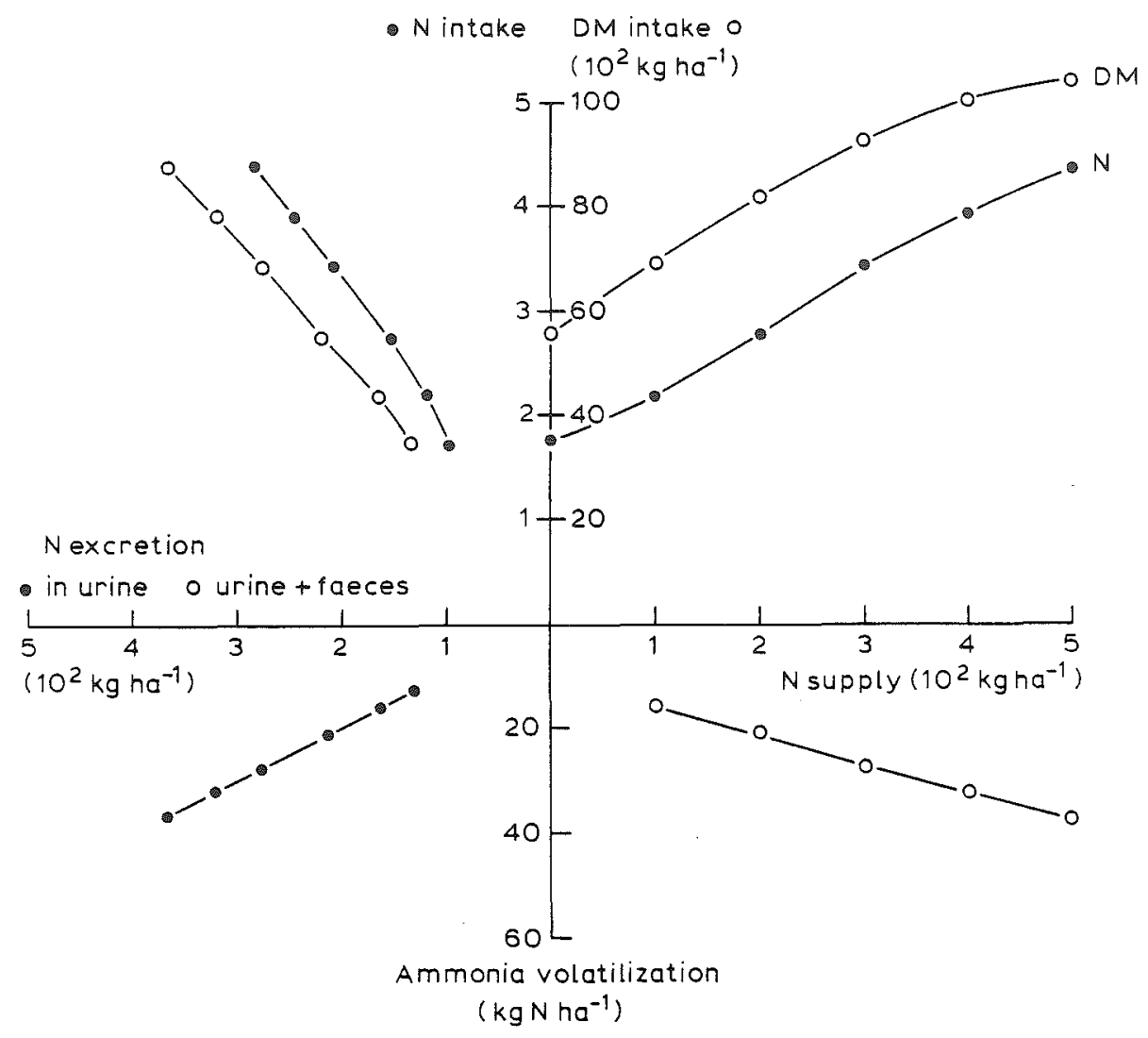

Fig. 4. Effect of $N$ supply on the dry matter (0) and $N(\bullet)$ intake during grazing, on the $\mathrm{N}$-excretion in urine ( ) and urine + faeces (0) and the resulting ammonia-N volatilization assuming $10 \%$ volatilization from excreted $\mathrm{N}$ in relation to $\mathrm{N}$-excretion ( $)$ and N-supply (o) .

For swards receiving $400 \mathrm{~kg} \mathrm{~N} . \mathrm{ha}^{-1}$ the calculated ammonia emissions are similar to the results of field measurements with the micrometeorological mass balance method (10). With lower N-supplies the ammonia volatilization as measured with the mass balance method decreases from $10 \%$ to approximately $5 \%$ of the $N$ returned to the sward. This discrepancy between the results of the mass balance and the windtunnel methods can be partly explained by the estimated $30 \%$ lower urine-N concentrations during grazing in low- $\mathrm{N}$ swards, as the relative ammonia emission is proportional 
to the urine- $N$ concentration (9). In addition the true emission seems to be underestimated by the mass balance method due to a relatively large background correction. For a reliable prediction of the ammonia emission more data on the urine $-\mathrm{N}$ concentration during grazing at different levels of $N$ supply have to be collected.

It can be concluded that the average ammonia-N emission from grazed pastures is limited to a maximum of $10 \%$ of the $\mathrm{N}$ returned to the field. In other words at least $90 \%$ of the excreted $N$ is not lost as ammonia.

6. REFERENCES

(1) VERTREGT, N. and RUTGERS, B. (1988). Ammonia volatilization from urine patches in grassland. In: V.C. Nielsen et al. (eds.) Volatile emissions from livestock farming and sewage operations pp. 85-91. Elsevier Applied Science, London.

(2) MOLEN, J. van der, et al. (1989). Ammonia volatilization from arable and grassland soils. In: Hansen, J.AA. and Henriksen, K. (eds.) Nitrogen in organic wastes applied to soils. pp. 185-201. Academic Press, London.

(3) LOCKYER, D.R. (1984). A system for the measurement in the field of losses of ammonia through volatilization. J. Sci. Fd. Agric. 35, $837-848$.

(4) DOAK, B.W. (1952). Some chemical changes in the nitrogenous constituents of urine when voided on pasture. J. Agric. Sci. 42, $162-171$.

(5) SHERLOCK, R.R. and GOH, K.M. (1985). Dynamics of ammonia volatilization from simulated urine patches and aqueous urea applied to pasture. II Theoretical derivation of a simplified iodel. Fertilizer Research 6, 3-22.

(6) VERTREGT, N. and RUTGERS, B. (1988). Ammonia volatilization from grazed pastures. CABO report 84 , Dutch priority programme on acidification, Report 64-2. CABO, Wageningen, 37 pp.

(7) MEER, H.G. van der and UUM-van LOHUIJZEN, M.G. van (1986). The relationship between inputs and outputs of nitrogen in intensive grassland systems. Developments in Plant and Soil Sciences, 23, 1-18. Martinus Nijhoff Publishers, Dordrecht.

(8) MEER, H.G. van der and MEEUWISSEN, P.C. (1989). Emissie van stikstof uit landbouwgronden in relatie tot bemesting en bedrijfsvoering. Landschap $6,19-23$.

(9) LANTINGA, E.A. et al. (1987). Distribution of excreted nitrogen by grazing cattle and its effect on sward quality, herbage production and utilization. In: H.G. van der Meer et al. (eds.) Animal manure on grassland and fodder crops. Martin Nijhoff Publishers, Dordrecht.

(10) JARVIS, D.C., HATCH, D.J. and ROBERTS, D.H. (1989). The effect of grassland management on nitrogen losses from grazed swards through ammonia volatilization; The relationship to excretal $\mathrm{N}$-returns from cattle. J. Agric. Sci. Camb. 112, 205-216. 